Arab Univ. J. Agric. Sci., Ain Shams Univ., Cairo, 14(1), 133-145, 2006

\title{
NOSOCOMIAL INFECTION IN SURGICAL HOSPITAL IN ZAGAZIG UNIVERSITY
}

\author{
Tohamy $^{1}$, E.Y.; A.M. Abo-Zeid ${ }^{2}$; A.A. Shaheen ${ }^{1}$ and \\ Samah F. El-Awadi ${ }^{1}$
}

\begin{abstract}
Surgical site infection (SSI) remains an important cause of morbidity and mortality among hospitalized patients. A total of 254 bacterial isolates were collected from 303 surgical specimens which were isolated from 92 males (53.2\%) and 81 females (46.8\%), their mean ages were 39.6 \pm 16.05 years (ranged from 1 month to 74 years). These isolates were identified as Staphylococcus aureus, Escherichia coli, Klebsiella pneumoniae, Proteus vulgaris, Pseudomonas aeruginosa and commensal Gram+ve and Gram-ve bacteria. The most effective antibiotics were imipenem while ampicillin and penicillin G (First and second generation of $\beta$-Lactam) showed much lower activity against all types of bacterial strains. The minimum inhibitory concentrations (MIC) of imipenem determined by E-test were $0.047-0.064,0.125,0.19,0.25$ and $0.75 \mu \mathrm{g} / \mathrm{ml}$ against Staphylococcus aureus, Escherichia coli, Proteus vulgaris, Klebsiella pneumoniae and Pseudomonas aeruginosa respectively.
\end{abstract}

Key words: Imipenem, Antibiotic susceptibility, Multi-drug resistance, Risk factors, Nosocomial infection

\section{INTRODUCTION}

Nosocomial infection (NI) remains an important cause of morbidity and mortality among hospitalized patients. It is an important clinical complication in adult and children patients in different hospital wards. It is associated with prolonged hospital stay and increased health care costs (Urea et al 2004). It may be endogenous arising from an infection agent present within a patient's body or exogenous transmitted from another source within the hospital (Aitken and Jeffris, 2001). The most important risk factors of mortality were observed to be nosocomial infection, older age, high (APACHE) II score (the mean of age, gender, acute, physiology and chronic health evaluation), mechanical ventilation, enteral nutrition, tracheotomy and use of steroids or chemotherapy (Coplan et al 2005). Diabetes mellitus, obesity and prolonged presence of a surgical drain increased the risk of infection (Vilar-Compte et al 2000). The risk of surgical site infection (SSI) increases also with the duration of surgery (Nateghian et al 2004). The

1- Department of Botany, Faculty of Science, Zagazig University, Zagazig, Egypt

2- Department of Microbiology, Faculty of Medicine, Zagazig University, Zagazig, Egypt

(Received June 18, 2005)

(Accepted July 4, 2005) 
emergence of resistant pathogens is an important factor in the morbidity and mortality of hospitalized patients (Nichols and Raad, 1999). Surgical site infection (SSI) is the most common in surgical patients accounting for 38\% of all such infections (Malone et al 2002). Ibrahim et al (1998) claimed that $31.25 \%$ of impatients have acquired surgical wound infections in the General Surgery department, Ain Shams University hospital (Egypt). Abu-Shady et al (1999) found that the most encountered nosocomial pathogens in Egypt were E. coli, P. aeruginosa, K. pneumonaie and Staph. aureus. The results of the study on the efficacy of nosocomial infection control (SENIC) project demonstrated that hospitals with active NI programs had lower rates of NI than those without such programs. A key component of these programs was the inclusion of a systematic method for monitoring NI and reporting these infections to clinicians, the preparation of surgical site infection (SSI) reports including the diagnosis of wound infection and parameters that allow comparison of infection rates to improve their perceptions regarding data accuracy and usefulness, post-discharge surveillance and information regarding pathogens, antibiotic sensitivities and co-morbidities of patients developing SSI are the most important categories for nosocomial infection control measures (Macbeth et al 2005).

Also, geographic information system is a part of the quality control system (Le Roux et al 2004).

Aim of the work: To determine the rate of nosocomial infection, identify the associated risk factors; study the antimicrobial resistance of bacterial isolates in order to evaluate the infection control measures in the Department of General Surgery in Zagazig University Hospitals (Egypt).

\section{MATERIAL AND METHODS}

\section{1- Collection of samples}

Samples were collected from inpatients after 48-72 hours of hospitalization in General Surgery Department of Zagazig University and delivered consecutively to the Microbiology Department. A total of 303 surgical specimens were collected from one hundred and seventy-three patients (91 males and 82 females) whose ages ranged from one month to 74 years. Specimens of pus were collected by swabbing wound with a sterile swab.

\section{2- Media used}

Different samples were cultured on C.L.E.D. agar, blood agar, MacConkey agar and Nutrient agar for their isolation and purification according to Murray et al (1999).

\section{3- Identification of bacterial isolates}

Conventional methods for the identification and characterization of isolates were employed according to Murray et al (1999), including colony morphology, Gram staining and biochemical reactions.

\section{4- Antibiotic susceptibility testing}

All isolates were tested for their invitro susceptibility to various antibiotics by disc diffusion testing according to Bauer et al (1966).

\section{5- Determination of minimum inhibito- ry concentration (MIC) using E-test \\ Minimum inhibitory concentration (MIC) of imipenem was determined against different multi-drug resistant strains (MRD) using E-test techniques (Epsilometer, $\mathrm{AB}$}


Biodisk, Solna, Sweden) following the manufacture's recommendations (Jacobs et al 1992).

\section{RESULTS}

During the study period, a total of 254 bacterial isolates were collected from 303 different clinical specimens, isolated from 92 males $(53.2 \%)$ and 81 females $(46.8 \%)$, whose mean ages were $39.6 \pm$ 16.05 years (ranged from 1 month to 74 years).

Data presented in Table (1) show the relation between numbers, percentage of inpatients during the period of June 2001 to July 2002 located in general Department of Zagazig University and the number of surgical specimens isolated from each patient.

The data from Table (2) claim that the highest incidence of bacterial strains isolated from 173 impatients was Staph. aureus being $37 \%$, while the lowest incidence of the strains was commensal gram +ve and gram-ve bacteria being $7.1 \%$. The other isolated bacterial strains ranged between $9.1 \%$ and $25.2 \%$.

Concerning the data in Table (3) the data showed that the most important risk factors affecting each patient in General Surgery Department were age, gender, surgical interference and presence of $\mathrm{Di}$ abetes mellitus (D.M.) since older age patients $(55.6 \%)$ were highly disposable to have nosocomial infection than younger age $(44.4 \%)$, also males $(54 \%)$ were higher than females $(46 \%)$ in their ability to have nosocomial infection from the hospital. Surgical interference also affected on dispersal of nosocomical infection in the hospital. Presence of D.M. were the most important reason for the ability of patient to have nosocomial infection.

Concerning the risk factors associated with nosocomial infection in General Surgery Department of Zagazig University Hospitals by multi-drug resistant strains (MDR), the obtained data in Table (3) show that the percentage of NI rate among 173 patients (92 males, 81 females) isolated from General Surgery Department of Zagazig University between 2001 and 2002, was $72.2 \%$.

\section{Susceptibility patterns for bacterial strains to various antibacterial agents by disc diffusion method}

Susceptibility patterns of bacterial strains to various antibacterial agents by disc diffusion method, showed that the most active antibiotics against all tested strains was imipenem, the susceptibility patterns of imipenem were $95.6 \%, 93.1 \%, 90.4 \%$, $84.6 \%, 78.1 \%$ against $P$. vulgaris, $K$. pneumoniae, Staph. aureus, E. coli and P. aeruginosa respectively. While the lower activity was showed by penicillin and ampicilline, where the susceptibility patterns of penicillin were $21.7 \%, 17.2 \%, 3.8 \%, 2.1$ and $0 \%$ against $P$. vulgaris, $K$. pneumoniae, E. coli, Staph. aureus and $P$. aerguinosa respectively and the susceptibility patterns of ampicillin were $21.7 \%, 20.2 \%, 13.7 \%, 0 \%$ and $0 \%$ against Proteus vulgaris, Staph. aureus, K. pneumoniae, E. coli and P.. aeruginosa respectively.

\section{DISCUSSION}

In the present study, a total of 254 bacterial isolates were collected from 303 surgical specimens isolated from 173 inpatients in General Surgery Department in Zagazig University (Egypt). 
Table 1. Demographic data:

\begin{tabular}{|cccc|}
\hline $\begin{array}{c}\text { No. of surgical } \\
\text { specimens }\end{array}$ & \multicolumn{2}{c}{$\begin{array}{c}\text { No. } \\
\text { of patients }\end{array}$} & $\begin{array}{c}\text { Total No. of surgical } \\
\text { specimens }\end{array}$ \\
\hline 1 & 90 & $(52.0)$ & 90 \\
2 & 47 & $(27.0)$ & 94 \\
3 & 27 & $(15.6)$ & 81 \\
4 & 8 & $(4.6)$ & 32 \\
6 & 1 & $(0.6)$ & 6 \\
\hline Total & 173 & 100 & 303 \\
\hline
\end{tabular}

Table 2. The percentage incidence of bacterial strains in different clinical Specimens

\begin{tabular}{|lcc|}
\hline \multirow{2}{*}{ Bacterial strains } & \multicolumn{2}{c|}{ Isolates } \\
\cline { 2 - 3 } & Total No. & $\%$ \\
\hline Staphylococcus aureus & 94 & 37 \\
Escherichia coli & 26 & 10.2 \\
Klebsiella pneumoniae & 29 & 11.4 \\
Proteus vulgaris & 23 & 9.1 \\
Pseudomonas aeruginosa & 64 & 25.2 \\
Commensal G+ve \& G-ve bacteria & 18 & 7.1 \\
\hline Total & 254 & 100 \\
\hline
\end{tabular}


Table 3. Risk factors associated with nosocomical infection in General Surgery Department of Zagazig University by different multidrug resistant strains (MDR)

\begin{tabular}{|c|c|c|c|c|c|}
\hline \multirow[t]{2}{*}{ Items } & \multirow{2}{*}{$\begin{array}{c}\text { No. } \\
n=173\end{array}$} & \multicolumn{2}{|c|}{$\begin{array}{c}+ \text { +ve Cultures } \\
n=126\end{array}$} & \multirow{2}{*}{$\begin{array}{c}\text { R.R. } \\
(\mathrm{CI}=95 \%)\end{array}$} & \multirow[t]{2}{*}{ P. Value } \\
\hline & & No & $\%$ & & \\
\hline \multicolumn{6}{|l|}{ 1- Age (years) } \\
\hline$\leq 40$ & 93 & 70 & 55.6 & 1.08 & 0.43 \\
\hline$>40$ & 80 & 56 & 44.4 & $(0.89-1.29$ & NS \\
\hline \multicolumn{6}{|l|}{ 2- Gender } \\
\hline Male & 92 & 68 & 54 & 1.03 & 0.73 \\
\hline Female & 81 & 58 & 46 & $(0.86-1.24)$ & NS \\
\hline \multicolumn{6}{|c|}{ 3- Surgical interference } \\
\hline Yes & 113 & 79 & 62.7 & 0.89 & 0.23 \\
\hline No & 60 & 47 & 37.3 & $(0.75-1.07)$ & NS \\
\hline \multicolumn{6}{|l|}{ 4- Presence of D.M. } \\
\hline Yes & 37 & 32 & 25.4 & 1.25 & $*$ \\
\hline No & 136 & 94 & 74.6 & $(1.06-1.48)$ & 0.3 \\
\hline $\begin{array}{l}\text { D.M. = Diabetes mellitus } \\
\text { CI = Confidence interval } \\
{ }^{*}=\text { Significance }\end{array}$ & $\begin{array}{l}\text { R.R }=\text { Relativ } \\
\text { NS = Non sig } \\
\mathrm{P}<0.05\end{array}$ & $\begin{array}{l}\text { risk } \\
\text { ficance }\end{array}$ & $\begin{array}{l}\mathrm{P}=1 \\
\mathrm{P}>\end{array}$ & $\begin{array}{l}\text { bability } \\
5\end{array}$ & \\
\hline
\end{tabular}

The results showed that Staphylococcus aureus, Pseudomonas aeruginosa, Klebsiella pneumoniae, Escherichia coli and Proteus vulgaris were the most commonly isolated pathogens from the different clinical specimens. These results are in agreement with those reported by Smith et al (2000), who found that the most frequent organisms were $P$. aeruginosa, P. mirabilis, E. Coli, K. pneumoniae, Staph. aureus and Entercocci. Also, Rangel-Frausto et al (1999) found that the microorganisms most commonly isolated were E. coli (28\%), Staph. aureus $(11.11 \%)$ and $P$. aeruginosa (8.6\%). Gransden (1997) also reported that the most frequent organisms isolated from a teaching hospital in U.K. were E. coli, $P$. aeurginara and $K$. species. The current susceptibility pattern of the isolated strains to different antibiotics was investigated.

The results showed that imipenem proved to have aboard spectrum and high activity against all the tested Grampositive and Gram-negative bacterial isolates.

The susceptibility rates of imipenem were $95.6 \%, 93.1 \%, 90.4 \%, 84.6 \%$ and $78.1 \%$ for $P$. vulgaris, $K$. pneumoniae, Staph. aureus, E. coli and P. aeruginosa respectively. These results are in accordance with data reported in other studies of Gowan et al (1989); Amyes \& Gemmell (1997). While pencillin $G$ and ampicillin showed the lowest activity against 
Table 5. Determination of minimum inhibitory Concentrations (MIC) of imipenem (IPM) against different multi-drug resistant strains using E-test

Multi-drug resistant strains

(MRD)

Methicilline resistant Staph. aureus (MRSA)

Escherichia coli

Proteus vulgaris

Klebsiella pneumoniae

Pseudomonas aeruginose

\section{E-test}

$\operatorname{MIC}(\mu \mathrm{g} / \mathrm{ml}) \quad$ Interpretation

$0.064-0.047 \quad S$

0.125

S

0.19

S

0.25

S

0.75

S

Fig. (1)

Staph. aureus

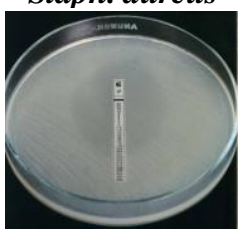

Fig. (3)

E. coli

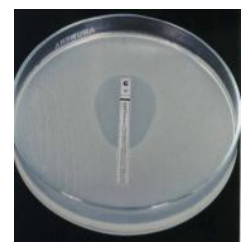

Fig. (2)

P. aeruginosa

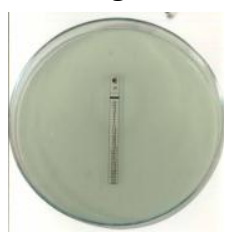

Fig. (4)

P. vulgaris

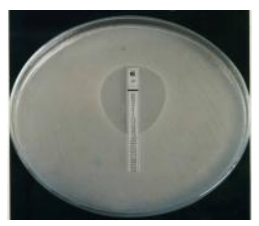

Fig. (5)

K. pneumoniae

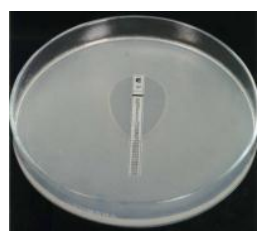

Fig. (1, 2, 3, 4 \& 5). Determination of minimum inhibitory concentrations (MIC) of imipenem (IPM) against different multidrug resistant strains using E-test 
all the tested Gram-positive and Gramnegative bacterial isolates. These results are not matched with the study of Matsukawa et al (2001), who found that penicillin's and first to second-generation cephalosporins (older antibacterial agents) can prevent bacterial infection except those caused by resistant microorganisms. In general, a high level of resistance among Staph. arueus, $P$. vulgaris, $P$. aeruginosa, E. coli and K. pneumoniae isolates to most cephalosporins tested was found in the present study. Contrasting to our results, Sammour et al (1995) in Egypt, Thornsberry \& Yee (1996) in USA and Gransden (1997) in U.K. obtained much lower percentage of resistance among the above organisms to cephalosporins. This confirm the finding of Tillotson et al (1997) and Davidson (1999) that the rates of antibiotic resistance vary markedly in different geographic regions, states, within the hospitals in the same geographic location and even among the various centers in the same hospital.

Susceptibility pattern of microorganisms to different antibiotics was affected mainly by the duration, dose, and interval of antibiotic administration. Kresken $\boldsymbol{e t}$ al (1994) reported that the resistant levels of $P$. aeruginosa to cioprofloxacin was $43.3 \%$ in Italy and 19\% in Greece, whilst in all other countries the incidence was $<10 \%$. These authors concluded that different use of antibiotics clearly affected the degree of resistance development. Bonfiglio et al (1998) concluded that the different levels of resistance found are in accordance with the low or high use of the drug in different centers. The Epsitometer-test (E-test) is a simple and reliable method for determining the susceptibility of bacterial isolates to many antibiotics. The results are comparable to those obtained with reference methods Mthwalo et al (1998); Freburg et al (1998) and Ho et al (1998), who found that disc diffusion tests perform satisfactory, but they yield categorized qualitative only and not MIC. The opinion of species-related breakpoints of the Swedish reference group for antibiotics (SRGA) is that the E-test is an important complement to recommend that disk diffusion screening methods for certain resistant mechanisms should be followed by E-test MIC- determination rather than by further disk testing. In present study, the susceptibility results of Staph. aureus, E. coli, K. pneumonaie, $P$. vulgaris and $P$. aeruginosa obtained with disc diffusion reference method were compared to those obtained with E-test. The data obtained indicate that there was a good correlation between disc diffusion test and E-test against different multidrug resistant isolates. The minimum inhibitory concentrations MIC of imipenem by E-test were $0.047-0.064,0.125,0.19,0.25,0.75$ $\mu \mathrm{g} / \mathrm{ml}$ against MRSA, E. coli, P. vulgaris, $K$. pneumoniae and $P$. aeruginosa. These results are in agreement with the results of Hanberger et al (1999) who found that MIC of imipenem against E.coli, $K$. spp., Enterobacter spp., $P$. spp. and $P$. aeruginosa were 100/100/98, 100/100/ $100,100,100,95,92 / 92 / 69$ and $84 / 84 / 84$ respectively according to the MIC breakpoints of the British Society for Antimicrobial Chemotherapy (BASC), the National Committee for Clinical Laboratory Standards (NCCLS) and the new speciesrelated breakpoints of the Swedish Reference Group for Antibiotics (SRGA) and comparable to the results of Tallis et al (1999) who found that MIC of imipenem against MSSA, P. aeruginosa and Entero- 
bacteriacae, was slightly superior to cefepime with only seven isolates resistant $(3 \%)$. In the present study, the overall nosocomial infection rate of 173 inpatients admitted to General Surgery Department in Zagazig university during the period from 2001 to 2002 was $72.8 \%$. These results are matched with the results of Atiken \& Jeffries (2001), who found that the incidence of NI is still higher than to be accepted. Although a complete elimination of NI is still far to be achieved, reduction of the incidence of these infection to a minimum level could be accomplished. The main risk factors associated with surgical wound infections were age, gender, presence of D.M. and surgical interference. The results showed that males $(53.2 \%)$ had higher NI rate than females $(46.8 \%)$, the post operative wound infections $(65.3 \%)$ were higher than that of preoperative wound infections $(34.7 \%)$ and the mean of age had higher NI was 39.6 \pm 16.05 years (older age had a risk factors of NI than young age); also D.M. cases (21.4\%) had higher NI rate than other cases. These results are in agreement with Coplan et al (2005) who found that the most important risk factors of mortality were observed as nosocomial infection, older age and high (APACHE) score, and Nateghian et al (2004) who found also that the risk of surgical site infection (SSI) increase with the duration of surgery and VazquezAragon et al (2003) who stated that the most frequent NI was surgical infection.

\section{RECOMMENDATIONS}

1- Early diagnosis and treatment is of critical importance to make infection control.
2- Even suspicion of infective postoperative complication should be sufficient cause to search for responsible microorganisms and begin antibiotic therapy.

3- Antimicrobial resistance should be seriously considered during surgical therapy and prophylaxis with antimicrobial agents.

4- Preparation of surgical site infection (SSI) reports including information, regarding pathogens, antibiotic sensitivities and co-morbidities of patients developing SSI.

\section{CONCLUSION}

From the previous data it is concluded that the most predominant organisms causing nosocomial infection was (37\%) Staphylococcus aureus and the most resistant organisms were Methicillin resistant Staphylococcus aureus (MRSA) and Pseudomonas aeruginosa. Also, the results showed that imipenem is the most effective antibiotics that could be used for treatment of multidrug resiatnt strains (which are important risk factors causing nosocomial infection).

\section{REFERENCES}

\footnotetext{
Abu-Shady, M.R.; M.K. Ibrahim; A.I. Kamel and H.I. Afyfy, (1999). Factors affecting hospital-acquired urosurgical infection. Egypt. J. Microbiol., 34(4): 629 - 643.

Aitken C. and D.J. Jeffries (2001). Nosocomial spread of viral disease. Clinical Mircob. Rev., 14(3): 528- 546.

Aitken C. and D.J. Jeffries (2001). Nosocomial spread of viral disease. Clinical Microb. Rev., 14(3): 558- 546.
} 
Amyes G.B. and C.G. Gemmell (1997). Antibioticresistance. J. Med. Mircobiol. 46(2): 436 - 470.

Bauer A.W.; W.M. Kirby.; J.C. Sherris and M. Truck (1966). Antibiotic susceptibility testing by the standard single disk method. J. Clin. Pathol., 45: 493 - 496.

Bennett J.V. and P.S. Brachman (1992). Epidemiology of Nosocomial Infections. Hospital Infection. $3^{\text {rd }}$ Edition, p. 154. Little Brown, Boston, U.S.A. Bonfiglio G.; V. Carciotto; G. Rnsso and S. Stefani (1998). Antibiotic resistance in $P$. aeruginosa: An Italian survey. J. Antimicrob. Chemother. 41(5): 307- 310.

Colpan, A.; E. Akinci; A. Erbay; N. Balaban and H. Bodur (2005). Evaluation of risk factors for mortality in intensive care unit: A prospective study from a referral hospital in Turkey. American Journal of Infective Control, 33(1): 4247.

Davidson, R.J. (1999). Canadian bacterial surveillance network, low D.E.A: Cross-Canada surveillance of antimicrobial resistance in respiratory tract pathogens. Can. J. Infect. Dis. 10(2): 128-133. Frausto, M.S.R.; D.M. Garcia; R.B. Martinez; J.I. Blances and S.P. Rosales del. (1999). Evaluation of a Nosocomial infection surveillance program. Salud Publica, Mex., 41(1): 559 - 563.

Freburg, N.B.; D. Nouet; L. Lemee and E. Martin (1998). Comparison of ATB Staph., Vitek and E-test methods for detection of oxacillin. Hetero-resistance in staphylococci possessing MecA. J. of Clinical Microbiology, 36(4): 52-57.

Gransden, W.R. (1997). Nosocomial gram-negative infection. In: antibiotic resistance S.G.B. Amyes and C.G. Gemmel eds., J. Med. Microbiol. 46(6): 436439.
Gowan, J.E.; E.C. Jr Hall and P.L. Parrott (1989). Antimicrobial susceptibility in gram-negative bacteremia are nosocomical isolates more resistant? $\boldsymbol{A n}$ timicorb. Agents Chemother. 39(11): 645 - 469.

Hanberger, H.; L.E. Nilsson; B. Claesson; A. Kärnell; $P$. Larsson; $M$. Rylander; E. Svensson; L.M. Sörberg and L. Sörén (1999). Breakpoints for early detection of development of resistance among Gram-negative bacteria in Swedish intensive care units. The British Society for Antimicrobial Chemotherapy, J. of Antimicrob. Chemothera. 44(16): 611 - 619.

Ho, P.L.; H. Chouk; K.Y. Yuen and P.Y. Chau (1998). Comparison of an inhibitorpotentiated-spectrum $\beta$-lactamases in $E$. coli and K. pneumomiae. J. Antimicrobial Chemotherapy, 42(11): 49 - 52.

Ibrahim, M.K.; M.S. Salama; R.M. Mostafa and H.M. Abu-Shady (1998). Studies on surgical wound nosocomial infections. J. Union Arab Biol., 6 (B): 115 - 127.

Ieven, M.; H. Jansens; D. Ursi; J. Verhoeven and $H$. Goossens (1995). Rapid detection of methicllin resistance in coagulase-negative staphylococci by Commercially Available fluorescence test. J. of Clin. Microbiol. 33(9): 2183 2185.

Jacobs，M.R.; S. Bajaksouzian; P.C. Appelbaum and A. Bolstrom (1992). Evaluation of the E-test for susceptibility testing of preumococci. Diagn. Mircobiol. Infect. Dis., 15(22): 473 - 485.

Kresken, M.; D. Hafner and H. Mittermayer (1994). Prevalence of fluoroquinolone resistance in Europe. Infection 22(2): 90 - 98.

LeRoux, P.; B. Marshall; F. Toutain; J.F. Mary; G. Pinon; E. Briquet and 
B. Leluyer (2004). Infections nosocomiales Virales dans un Service de Pédiatrie: L'exemple des Gastroentéritis a' Rotavirus et des Bronchlites a' VRS. Archives de Pediatrie 11(8): 908 - 915.

Macbeth, D.; G. Gardner; M. Wallis and J. Gerrard (2005). Surgeons' perspectives on surgical wound infection rate data in Queensland, Australia. American Journal of Infection Control, 33(2): 79 103.

Malone, D.L.; T. Genuit; J.K. Tracy; C. Gannon and L.M. Napolitano (2002). Surgical site infections: reanalysis of risk factors. Journal Surgical Research, 103(1): 89- 95. Matsukawa, M.; Y. Kunishima; S. Takahashi; K. Takeyama and T. Tsukamoto (2001). Staphylococcus aureus Bacteriuria and Surgical Site Infections by methicllin-resistant Staphylococcus aureus. Int. J. Antimicrob Agents, 17 (4): 9 - 327.

Mthwalo, M.; A. Wases; R. Huebner; H.J. Koornhof and K.P. Klugman (1998). Antibiotic resistance of nasopharyngeal isolates of Str. pneumoniae from children in Lesotho. Bulletin of the World Health Organization, 76(3): 641 650.

Murrary, P.R.; E.J. Baron; M.A. Pfaller; F.C. Tenover and R.H. Yolken (1999). Manual of clinical microbiology. American Society for Microbiology $7^{\text {th }}$ Edition, p. 145. Nateghian, A.; G.Taylor and J.L. Robinson (2004). Risk factors for surgical site infection following open-heart surgery in a Canadian Pediatric Population. American Journal of Infection Control, 32(7): 397- 401.

Nichols, R.L. and I.I. Raad (1999). Management of bacterial complications in critically Ill Patients: surgical wound and catheter-related infections. Diagnos- tic Microbiology and Infectious Disease 33(2): 121 - 130.

Rangel-Frausto, M.S.; D. MoralesGarcia; R. Baez-Martinez; J. IbarraBalnces and S. Ponce de Leon-Rosales (1999). Evaluation of a nosocomial infection surveillance program. Salud Publica Mex., 41(1): 59-63.

Sammour, S.H.; A. Shaheen; E. Selim; S.A. Doss and M.S. Sabbour (1995). Incidence of antibiotic resistance among hospital pathogens and commensal flora in urban and rural areas. Egypt. J. Med. Mircobiol. 4(7): 321- 326.

Smith, P.W.; C.W. Seip; S.C. Schaefer and C. Bell-Dixon (2000). Microbiology survey of long-term care facilities. American Journal of Infection Control, 28 (1): 8-13.

Tallis E.; B. Rudensky; D. Attias; D. Raveh; Y. Schlesinger and A.M. Yinnon (1999). In-vitro activity of cefepime and other broad-spectrum antimicrobial againsts several groups of Gram-negative bacilli and Staphylococcus aureus. Diagnostic Microbiology and Infectious Disease, 35(2): 121-126.

Thornsberry, C. and C. Yee (1996). Comparative activity of eight antimicrobial agents against clinical bacterial isolates from the United States, measured by two methods. Am. J. Med. 100(11): 265 385.

Tillotson G.S.; J. Dorrian and J. Blondeau (1997). Flouroquinolone resistance:

mechanisms and epidemiology, in antibiotic resistance. Amyes, S.G. and C.D. Gemmell eds. J. Med. Microbiol. 46(6): 436 - 470.

Urea, M.; S. Rives; O. Cruz; A. Navarro; J..J. Garcia and J. Estella (2004). Nosocomial infections among pediatric hematology / oncology patients: results of a prospective incidence study. American Journal of Infection Control. 32(4): 205 - 208. 
Vazquez-Aragon, P.; M. Lizan Garcia; P. Cascales-Sanchez; M.T. VillarCanovas and D. Garcia-Olmo (2003). Nosocomial infection and related risk factors in a general surgery service: a prospective study. J. of Infection, 46(1): 17-22.

Vilar-Compte, D.; A. Mohar; S. Sandoval; M. de La Rosa; P. Gordillo and P. Volkow (2000). Surgical site infection at the National Center Institute in Mexico: a case-control study. Am. J. Infect Control 28 (1): 14-20.
Weller, T.M.A.; D.W. Crook; M.R. Crow; W. Ibrahim; T.H. Pennington and J.B. Selkon (1997). Methicillin susceptibility testing of Staphylococci by E-test and Comparison with Agar Dilution and MecA Detection. J. Antimicrob. Chemother. 39(13): 251 - 253.

Woodford, N.; A.P. Johnson; D. Morrison and D.C.E. Speller (1995). Current perspectives on glycopeptide resistance. Clin. Microbiol. Rev. 8(1): 585 - 615.

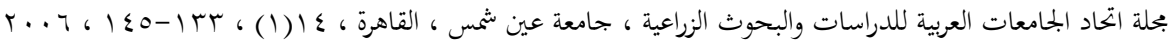

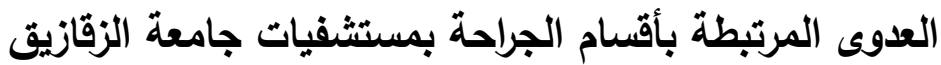

[9]

$$
\begin{aligned}
& \text { إيمان يوسف تهامى' - عزه عبد العزيز مهنى أبو زيد' - احم أنور شاهين' - }
\end{aligned}
$$

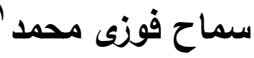

$$
\begin{aligned}
& \text { 1- قسم النبات - كلية العلوم - جامعة الزقازيق - مصر }
\end{aligned}
$$

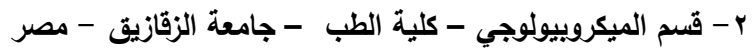

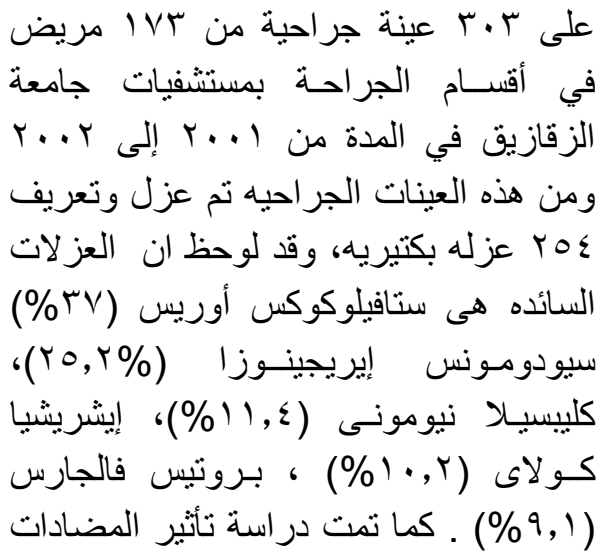

$$
\begin{aligned}
& \text { تعتبر المستشفيات من الأماكن الهامة } \\
& \text { لانتشار العدوى التى تـؤدى إلى حالات التى الته } \\
& \text { مرضية وقد تؤدى فى النهايه إلى الوفاة بين } \\
& \text { المرضى المتو اجدين في المستشفى. ويهدف } \\
& \text { هذا البحث إلى تحديد نسبة العدوى في في العين } \\
& \text { المستشفيـات، وتعـريف العوامل المرتبطة }
\end{aligned}
$$

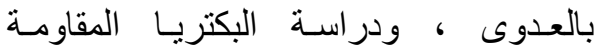

$$
\begin{aligned}
& \text { للمضـادات الحيويـة، وتقييم عملية مكافحة } \\
& \text { العدوى في أقسـام الجراحة بمستشفيات } \\
& \text { جامعة الزقازيق (ج.م.ع). وقد نم الحصول }
\end{aligned}
$$




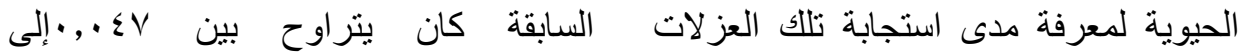

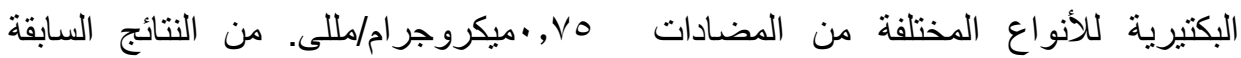

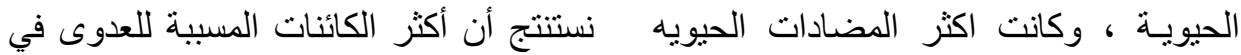

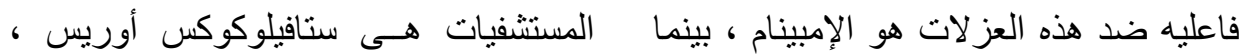

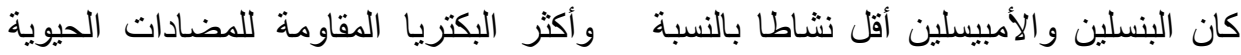

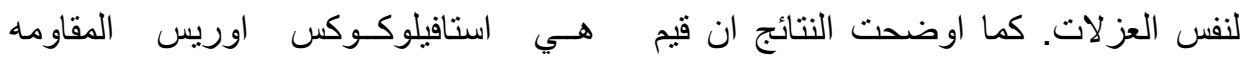
أقل تركيز مثبط من الإمبينام ضد العزل العات للميثيسلين وسيدومونس إيريجينوزا.

تحكيم: أ.د ر راويـة فتحى جمـال أ.د محمد يسرى الدخاخنى 